\title{
PENGARUH PENDEKATAN PEMBELAJARAN "SKILL- DRILL-GAME" TERHADAP PENINGKATAN HASIL BELAJAR PENDIDIKAN JASMANI
}

\author{
Aris Risyanto ${ }^{1}$ \\ ${ }^{1}$ Pendidikan Jasmani Kesehatan dan Rekreasi, Fakultas Keguruan dan Ilmu Pendidikan, \\ Universitas Subang, Indonesia \\ arisrisyanto@unsub.ac.id ${ }^{1}$
}

\begin{tabular}{ll}
\hline Info Artikel & Abstrak \\
\hline Sejarah Artikel: & Masalah dalam penelitian ini adalah rendahnya hasil belajar \\
Diterima Maret 2020 & siswa dalam pembelajaran pendidikan jasmani. Tujuan \\
Disetujui April 2020 & penelitian ini adalah untuk mengetahui pengaruh pendekatan \\
Dipublikasikan Juni 2020 & pembelajaran "skill-drill-game"(SDG) terhadap peningkatan \\
& hasil belajar pendidikan jasmani di SMPN 2 Sidamulih \\
& Kecamatan Sidamulih Kabupaten Pangandaran. Metode yang \\
& digunakan adalah metode eksperimen dengan menggunakan \\
& pretest-posttest design. Sampel dalam penelitian ini adalah \\
& sebagian siswa kelas VIII SMPN 2 Sidamulih yang terdiri dari \\
& 1 kelas eksperimen. Dari hasil penelitian, menunjukkan bahwa \\
& terdapat pengaruh positif antara pendekatan pembelajaran \\
& "skill-drill-game" terhadap peningkatan hasil belajar \\
& pendidikan jasmani. Dalam penelitian ini, pengujian hipotesis \\
& menggunakan perhitungan Paired Samples T Test. \\
& Berdasarkan hasil penelitian, pendekatan pembelajaran "skill- \\
& drill-game" terlihat mampu meningkatkan hasil belajar \\
& pendidikan jasmani. Maka dapat disimpulkan bahwa \\
& pendekatan pembelajaran "skill-drill-game" berpengaruh \\
& positif terhadap peningkatan hasil belajar siswa pada mata \\
& pelajaran pendidikan jasmani .
\end{tabular}

kata kunci :

Hasil Belajar Pendidikan

Jasmani, Pendekatan

Abstrack

Pembelajaran "Skill-Drill-

Game".

keyword:

Physical Education Learning

Outcomes, "Skill-Drill-Game"

Learning Approach.

The problem in this study is the low student learning outcomes in physical education learning. The purpose of this study was to determine the effect of the "skill-drill-game" (SDG) learning approach to improving physical education learning outcomes at SMPN 2 Sidamulih, Sidamulih District, Pangandaran Regency. The method used is an experimental method using pretest-posttest design. The sample in this study were some of the eighth grade students of SMPN 2 Sidamulih consisting of 1 experimental class. From the research results, it shows that there is a positive influence between the "skilldrill-game" learning approach to the improvement of physical education learning outcomes. In this research, hypothesis testing uses Paired Samples T Test calculations. Based on the results of the study, the "skill-drill-game" learning approach seems to be able to improve physical education learning 
outcomes. Then it can be concluded that the "skill-drill-game" learning approach has a positive effect on improving student learning outcomes in physical education subjects.

(C) 2020 Universitas Suryakancana

\section{PENDAHULUAN}

Pada masa sekarang ini, permasalahan yang menjadi suatu kendala bagi masyarakat global yaitu mengenai penyakit kurang gerak (hipokinetik) yang terjadi pada anakanak sehingga menghambat pada pertumbuhan dan kebugaran jasmani mereka. Kebiasaan kurang gerak ini semakin meningkat tiap tahunnya, hal ini terbukti dari data WHO yang menyebutkan bahwa pada saat ini setidaknya $60 \%$ populasi dunia tidak melakukan olahraga yang cukup. Hal ini terutama disebabkan oleh bertambahnya penggunaan transportasi mekanik dan bertambahnya teknologi hemat tenaga fisik yang ada di rumah.

Pada anak-anak, penurunan aktivitas fisik tampaknya terjadi karena kurang berjalan kaki dan kurangnya pelajaran olah raga. Kecenderungan dunia dalam mengisi waktu luang secara aktif tampak kurang nyata. WHO juga menyatakan bahwa orang di seluruh dunia kurang mencari kegiatan rekreasi yang melibatkan aktivitas fisik.

(MS. Taufik, 2019) Menurunnya tingkat kebugaran jasmani dan hasil belajar pada mata pelajaran pendidikan jasmani merupakan salahsatu dampak nyata yang terlihat.
Salah satu faktor yang berpengaruh terhadap hasil belajar siswa yaitu pendekatan pembelajaran "skill-drillgame".

Hasil belajar menurut (Winnico, MG Gaos, 2019) adalah perubahan tingkah laku secara relatif permanen dan secara potensial terjadi sebagai hasil dari praktik atau penguatan (reinforced practice) yang dilandasi tujuan tertentu.(Saputra, 2020) mengemukakan bahwa " hasil belajar adalah seperangkat proses kognitif yang mengubah sifat stimulasi lingkungan, melewati pengolahan informasi, menjadi kapabilitas baru." Untuk mengatasi timbulnya kejenuhan siswa, maka diharapkan guru atau pihak sekolah melakukan usaha-usaha yang dapat membangkitkan terhadap peningkatan hasil belajar yang salahsatunya dengan menggunakan pendekatan pembelajaran "skill-drill-game".

\section{METODE}

Populasi

Berdasarkan rumusan di atas maka dalam penelitian ini populasinya adalah siswa kelas VIII SMPN 2 Sidamulih. Yang terinci sebagai berikut:

$\begin{array}{ll}\text { VIII A : } & 25 \text { orang siswa } \\ \text { VIII B : } & 21 \text { orang siswa }\end{array}$


17| Aris Risyanto

Pengaruh Pendekatan Pembelajaran "Skill-Drill-Game" Terhadap Peningkatan Hasil Belajar Pendidikan Jasmani

VIII C : $\quad 25$ orang siswa

VIII D : $\quad 23$ orang siswa

Jumlah : $\quad 94$ orang siswa

Sampling

Teknik sampling yang digunakan

adalah Probability Sampling yang "memungkinkan setiap anggota populasi yang sama untuk terpilih menjadi anggota sampel” (Ali, 2012,hlm.55). Pada penelitian ini, teknik yang digunakan adalah "cluster random sampling" yaitu menetapkan sampel penelitian berdasarkan kelompok atau daerah. Menurut Riduwan (2010,hlm.60) "cluster sampling adalah sebuah teknik sampling yang dilakukan dengan cara mengambil perwakilan atau mengambil salahsatu kelas dari setiap kelas yang ada."

Sampel Penelitian

Sampel adalah sebagian atau wakil populasi yang diteliti. Sampel yang digunakan dalam penelitian ini adalah dengan menentukan satu kelas yang akan dijadikan kelas penelitian. Disini peneliti melakukan random assignment untuk mengambil satu kelas eksperimen. Dari seluruh kelas populasi tersebut, peneliti mengambil satu kelas sampel secara random. Setelah dilakukan pengambilan sampel, dan yang keluar menjadi kelas eksperimen dalam penelitian ini adalah kelas VIII D sebanyak 23 orang. Jadi jumlah keseluruhan sampel dalam penelitian ini adalah 23 orang.

Metode Penelitian

Metode yang digunakan dalam penelitian ini adalah metode kuasi eksperimen dengan pendekatan kuantitatif, hal ini disebabkan karena dalam penelitian ini fokus kajian dan pengukuran adalah pada aspek prilaku yang hasilnya berupa angka dengan menggunakan kelas kontrol sebagai pembanding. Setelah diperoleh sampel secara cluster random sampling kemudian kelas tersebut dijadikan sebagai kelas penelitian. Disain penelitiannya sebagai berikut:

Treatment group

$\begin{array}{llll}\mathrm{R} & \mathrm{O} & \mathrm{X} & \mathrm{O}\end{array}$

Keterangan:

$\mathrm{R}=$ Random (Penetapan secara acak pada kelas VIII yang dipilih secara random)

$\mathrm{O}=$ Observasi atau pengukuran

$\mathrm{X}=$ Eksperimen (Model Pembelajaran

Skill-Drill-Game)

Instrument Penelitian

Untuk memperoleh data yang akurat dan relevan dengan masalah yang diteliti, penulis menggunakan teknik pengumpulan data sebagai berikut:

Penerapan pendekatan pembelajaran "skilldrill-game" dalam berbagai model pembelajaran yang mengacu pada peningkatan hasil belajar siswa.

Teknik ini dipergunakan untuk merangsang keaktifan belajar dan keaktivan siswa dalam proses pembelajaran. Teknik ini juga berfungsi untuk mengumpulkan data mengenai hasil belajar siswa kelas VIII pada mata pelajaran pendidikan jasmani. Sehingga di harapkan terdapat perubahan pada aspek hasil belajar siswa. 
18| Aris Risyanto

Pengaruh Pendekatan Pembelajaran "Skill-Drill-Game" Terhadap Peningkatan Hasil Belajar Pendidikan Jasmani

Instrument pengukuran hasil belajar siswa yang di kutip dari Suherman (2013)

\begin{tabular}{|c|c|c|c|c|c|}
\hline \multirow{2}{*}{$\mathrm{N}$} & \multirow{2}{*}{$\begin{array}{l}\text { Kompon } \\
\text { en yang } \\
\text { dinilai }\end{array}$} & \multicolumn{4}{|c|}{ Kriteria } \\
\hline & & $\begin{array}{l}\text { Baik } \\
\text { sekali } \\
(4)\end{array}$ & Baik (3) & $\begin{array}{l}\text { Cukup(2 } \\
\text { ) }\end{array}$ & $\begin{array}{l}\text { Perlu } \\
\text { bimbingan } \\
\text { (1) }\end{array}$ \\
\hline 1 & $\begin{array}{l}\text { KD \& } \\
\text { indikator }\end{array}$ & Selalu & $\begin{array}{l}\text { Sebagian } \\
\text { besar }\end{array}$ & $\begin{array}{l}\text { Kadang- } \\
\text { kadang }\end{array}$ & Kurang \\
\hline 2 & $\begin{array}{l}\text { KD \& } \\
\text { indikator }\end{array}$ & Selalu & $\begin{array}{l}\text { Sebagian } \\
\text { besar }\end{array}$ & $\begin{array}{l}\text { Kadang- } \\
\text { kadang }\end{array}$ & Kurang \\
\hline 3 & $\begin{array}{l}\text { KD \& } \\
\text { indikator }\end{array}$ & Selalu & $\begin{array}{l}\text { Sebagian } \\
\text { besar }\end{array}$ & $\begin{array}{l}\text { Kadang- } \\
\text { kadang }\end{array}$ & Kurang \\
\hline
\end{tabular}

Uji Validitas

Untuk menguji tingkat validitas dari instrument dengan menggunakan rumus korelasi product moment

rxy

$$
\frac{\mathrm{n} \sum \mathrm{xy}-\left(\sum \mathrm{x}\right)\left(\sum \mathrm{y}\right)}{\sqrt{\left\{\mathrm{n} \sum \mathrm{x}^{2}-\left(\sum \mathrm{x}\right)^{2}\right\}\left\{\mathrm{n} \sum \mathrm{y}^{2}-\left(\sum \mathrm{y}\right)^{2}\right\}}}
$$

(Suharsimi Arikunto, 2002: 146)

Dimana:

$\mathrm{rxy}=$ Koefisien korelasi antara variabel $\mathrm{X}$ dan variabel $\mathrm{Y}$, dua variabel yang dikorelasikan.

$\begin{array}{lll}\mathrm{x} & = & \text { Skor tiap items } \\ \mathrm{y} & = & \text { Skor total items } \\ \mathrm{n} & = & \text { Jumlah responden uji coba }\end{array}$

\begin{tabular}{|l|l|l|l|l|l|}
\hline $\begin{array}{l}\text { Kelompok } \\
\text { Sampel }\end{array}$ & N & $\begin{array}{l}\text { Rata- } \\
\text { rata }\end{array}$ & $\begin{array}{l}\text { Standar } \\
\text { Deviasi }\end{array}$ & $\begin{array}{l}\text { Skor } \\
\text { Terendah }\end{array}$ & $\begin{array}{l}\text { Skor } \\
\text { Tertinggi }\end{array}$ \\
\hline $\begin{array}{l}\text { Pembelajaran } \\
\text { Skill-Drill- } \\
\text { Game }\end{array}$ & 23 & 85,91 & 7,555 & 71 & 97 \\
\hline
\end{tabular}

Uji Reliabilitas
Menghitung reliabilitas instrument dengan menggunakan rumus Alpha. Rumus Alpha digunakan untuk mencari reliabilitas instrument angket atau soal bentuk uraian.

$\mathrm{r} 11=\left(\frac{k}{k-1}\right)\left(\frac{\sum S_{i}}{S_{t}}\right)$

Dimana:

r11 = Nilai reliabilitas

$k \quad=$ jumlah item

$\sum^{S_{i}} \quad=$ Jumlah varian skor tiap item

$S_{t} \quad=$ Varian total

(Suharsimi Arikunto, 2010:109)

\section{Uji t hitung}

Untuk membuktikan besarnya pengaruh variabel $\mathrm{X}$ terhadap variabel $\mathrm{Y}$ yang didapat harus diuji signifikasinya, maka dilakukan dengan menggunakan statistik hitung $t$ dengan rumus:

$\mathrm{t}$ hitung $=\frac{r \sqrt{n-2}}{\sqrt{1-r^{2}}}$

Keterangan :

$\mathrm{r} \quad=$ Korelasi

$\mathrm{n} \quad=$ Jumlah sampel

$\mathrm{t}=\mathrm{t}$ hitung yang selanjutnya dibandingkan dengan $t$ tabel

Untuk lebih menghemat waktu, pengolahan data dapat juga diselaikan melalui program komputer yaitu dengan menggunakan program SPSS for Windows.

Hasil Penghitungan Nilai Rata-rata dan Simpangan Baku 
19| Aris Risyanto ${ }^{1}$

Pengaruh Pendekatan Pembelajaran "Skill-Drill-Game" Terhadap Peningkatan Hasil Belajar Pendidikan Jasmani

Perhitungan nilai rata-rata, simpangan baku, dan varians dari setiap tes dapat dilihat dan untuk perhitungannya menggunakan IBM SPSS statistics 18.

Hasil Penghitungan Nilai Rata-rata dan Simpangan Baku

\begin{tabular}{|l|l|l|l|l|}
\hline No & Variabel & P-value & $\begin{array}{l}\text { Probalit } \\
\text { as }\end{array}$ & Ket. \\
\hline 1. & $\begin{array}{l}\text { Metode } \\
\text { Pembelajaran SDG }\end{array}$ & 0,560 & $>0.05$ & Normal \\
\hline
\end{tabular}

Hasil Perhitungan Uji Normalitas Data

Kemudian langkah selanjutnya adalah melakukan uji normalitas data pada hasil belajar siswa. Uji normalitas data dilakukan untuk mengetahui apakah data yang diperoleh dan akan diuji berada pada taraf ditribusi normal atau tidak. Dalam uji normalitas data hasil belajar siswa, penulis masih menggunakan bantuan program SPSS 18.

Penghitungan Uji Normalitas

Berdasarkan tabel ringkasan di atas dengan demikian dapat dinyatakan bahwa distribusi data dari masing-masing variabel berdistribusi normal. Data tersebut menyatakan bahwa dengan pengujian normalitas didasari oleh nilai probabilitas yang dibandingkan dengan nilai derajat kebebasan yaitu sebesar $\alpha=0,05$. Dari data metode pembelajaran "skill-drill-game" sebesar 0,690. Hal ini menyatakan bahwa nilai signifikansi berada pada distribusi normal.

\begin{tabular}{|l|l|l|l|l|}
\hline N & Nama Variabel & $\begin{array}{l}\text { Kolmo } \\
\text { gorov } \\
\text { o }\end{array}$ & $\begin{array}{l}\text { Probal } \\
\text { Smirno } \\
\text { va }\end{array}$ & Ket. \\
\hline 1 & $\begin{array}{l}\text { Metode } \\
\text { Pembelajaran SDG }\end{array}$ & 0,690 & $>0.05$ & $\begin{array}{l}\text { Nor } \\
\text { mal }\end{array}$ \\
\hline
\end{tabular}

Pengujian Homogenitas

Agar mempermudah dalam proses perhitungan uji homogenitas peneliti menggunakan SPSS statistics 18 yang dapat dilihat pada tabel 4.4 dan untuk perhitungan dapat dilihat pada lampiran.

Penghitungan Uji Homogenitas

Berdasarkan tabel ringkasan di atas dengan demikian dapat dinyatakan bahwa distribusi data dari masing-masing variabel berdistribusi homogen

Pengujian Hipotesis

Selanjutnya untuk menjawab hipotesis yaitu terdapat pengaruh positif dari pendekatan pembelajaran skill-drill-game terhadap peningkatan hasil belajar siswa dalam pelajaran pendidikan jasmani masih menggunakan perhitungan Paired Samples T Test pada SPSS statistics 18 dapat dilihat pada tabel dan untuk perhitungan dapat dilihat sebagai berikut.

Perbandingan Nilai Rata-Rata pretest Hasil Belajar Siswa dan posttest Hasil Belajar Siswa 
20|Aris Risyanto ${ }^{1}$

Pengaruh Pendekatan Pembelajaran "Skill-Drill-Game" Terhadap Peningkatan Hasil Belajar Pendidikan Jasmani

Berdasarkan data tersebut dapat diketahui bahwa pendekatan pembelajaran (skilldrill-game) berpengaruh positif terhadap peningkatan hasil belajar siswa dalam mata pelajaran pendidikan jasmani. Terbukti bahwa nilai hasil belajar siswa yang diberikan perlakuan pembelajaran skilldrill-game nilai posttest nya lebih tinggi sebesar $(78,91)$ daripada nilai pretest hasil belajar siswa sebesar $(71,78)$ Dengan ini dapat disimpulkan pula bahwa adanya treatment pendekatan pembelajaran skilldrill-game berpengaruh signifikan terhadap peningkatan hasil belajar siswa dalam mata pelajaran pendidikan jasmani di SMPN 2 Sidamulih Kec. Sidamulih Kab. Pangandaran.

\begin{tabular}{|c|c|c|c|c|}
\hline \multirow[b]{2}{*}{ No } & \multirow[b]{2}{*}{ Variabel } & \multicolumn{2}{|c|}{ Hasil Belajar } & \multirow[b]{2}{*}{ Selisih } \\
\hline & & $\begin{array}{l}\text { Mean } \\
\text { pretest }\end{array}$ & $\begin{array}{l}\text { Mean } \\
\text { posttest }\end{array}$ & \\
\hline 1. & $\begin{array}{l}\text { Metode } \\
\text { Pembelajaran } \\
\text { Skill-Drill- } \\
\text { Game }\end{array}$ & 71,78 & 78,91 & 7,13 \\
\hline
\end{tabular}

\section{Kesimpulan}

Berdasarkan hasil pengolahan data dan analisis data yang telah dilakukan, maka dapat diambil kesimpulan sebagai berikut: "Pendekatan pembelajaran "Skill-DrillGame" berpengaruh positif terhadap peningkatan hasil belajar siswa dalam mata pelajaran pendidikan jasmani."

DAFTAR PUSTAKA
Perlman, D. (2012). The Influence of the Sport Education Model on Amotivated Students' In-Class Physical Activity, Australia : SAGE

Ali, M.(2011). Memahami Riset Prilaku Dan Sosial. Bandung: CV Pustaka Cendikia Utama.

Arikunto, S.(2010). Prosedur Penelitian Suatu Pendekatan Praktek. Jakarta: Rineka Cipta.

Fraenkel, Jack.R.(2012). How To Design And Evaluate Research In Education. New York: The McGraw Hill Companies.

Giriwijoyo, S.Y.S. (2012). Ilmu Kesehatan Olahraga. Bandung: PT Remaja Rosdakarya.

Mahendra, A. (2009). Asas dan Falsafah Pendidikan Jasmani. Bandung: FPOK UPI.

Maksum, A. (2012). Metodologi Penelitian Dalam Olahraga. Surabaya: Unesa University.

Mudjiono. dan Dimyati. (2006). Belajar dan Pembelajaran.Jakarta:

RinekaCipta.

Nazir, M. (2005). Metode Penelitian.Bogor: Ghalia Indonesia.

Priyatno, D. (2010). Teknik Mudah dan Cepat Melakukan Analisis Data Penelitian dengan SPSS dan Tanya Jawab Ujian Pendadaran, Yogyakarta: Gava Media.

Riduwan.(2010). Metode dan Teknik Menyusun Tesis.Bandung: Alfabeta. 
21 Aris Risyanto ${ }^{1}$

Pengaruh Pendekatan Pembelajaran "Skill-Drill-Game"

Terhadap Peningkatan Hasil Belajar Pendidikan Jasmani

Rusman.(2012).Model-Model

Pembelajaran.Jakarta:

PT

Rajagrafindo Persada.

Santoso, S. (2013). Mengusai SPSS 21 di

Era Informasi. Jakarta: PT Elex

Media Komputindo

Saputra, Y. Dkk. (2007). Filsafat Penjas,

Kesehatan, dan Rekreasi. Bandung:

FPOK UPI.

Slameto.(2010). Belajar dan Faktor-Faktor

yang Mempengaruhinya. Jakarta:

RinekaCipta.

Somarya, D. dan Nuryani, P. (2007)

Landasan Pendidikan, Bandung:

UPI.

Sudjana, N. (2005). Metoda Statistika.

Bandung: Tarsito.

Sudjana, N. (2009). Penilaian Hasil Proses

BelajarMengajar. Bandung: PT

Remaja Rosdakarya.

Sugiono. (2011). Metode Penelitian

Kuantitatif, Kualitatif dan R\&D.

Bandung: Alfabeta.

Suherman, A. (2009). Revitalisasi

Pengajaran Dalam Pendidikan

Jasmani. Bandung: CV Bintang

Warli Artika.

Suprihatiningrum, J. (2013). Strategi

Pembelajaran Teori \& Aplikasi.

Jogjakarta: Ar-Ruzz Media.

Syah, M. M. (2010).Psikologi

Pendidikan:Dengan Pendekatan

Baru. Bandung: PT Remaja

Rosdakarya.

Undang-Undang No.20 tentang Sistem

Pendidikan

Nasional
(SISDIKNAS). Bandung: Citra

Umbara.

Ms. Taufik (2018), Meningkatkan

Teknik Dasar Dribbling

Sepakbola Melalui Modifikasi

Permainan Jurnal Pendidikan

Jasmani Kesehatan Dan

Rekreasi 8 Halaman 2 Penerbit Jurnal Maenpo

Ms. Taufik. (2019). Hubungan Tingkat Konsentrasi Dengan Keterampilan Bermain Futsal Unit Kegiatan Mahasiswa Futsal Universitas Suryakancana Dalam Olahraga. Gladi Jurnal Unj, 10(02), 68-78. Https://Doi.Org/Doi :

Https://Doi.Org/10.21009/Gjik.102.0 1

Saputra, H. (2020). Model Pembelajaran Direct Intruction Dan Model Pembelajaran Tgt Teams Games Tournament Terhadap Peningkatan Kemampuan Keterampilan Lay-Up Shoot Dalam Permainan Bola Basket Pada Siswa Kelas Xi Smk Pasundan 1 Cianjur. Maenpo, 8(2), 16. Https://Doi.Org/10.35194/Jm.V8i2.9 25

Winnico, Mg Gaos, M. T. (2019). Peningkatan Keterampilan Shooting Kaki Bagian Dalammelalui AudioVisual. Maenpo, 09(1), 1-7.

Akin, Y.(2010). Pengaruh Permainan Outbond Terhadap Kemampuan Berpikir Kritis Siswa SMP. Bandung: Tidak Diterbitkan. 
22| Aris Risyanto ${ }^{1}$

Pengaruh Pendekatan Pembelajaran "Skill-Drill-Game"

Terhadap Peningkatan Hasil Belajar Pendidikan Jasmani

Murni, A. (2010). Pengaruh Penerapan

Model Pembelajaran Student

Centered Learning Terhadap Hasil

Belajar Dengan Motivasi Belajar

Sebagai Variabel Intervening.

Pedagogia Jurnal Ilmu Pendidikan,

8 (3), hlm. 1-16.

Robinys.(2013). Teacher-Centered

Learning (TCL) dan Student

Centered Learning (SCL).

[Online]. Tersedia di:

http://robinys.blogspot.com/2013/0

6/teacher-centered-learning-tcl-

dan.html

Makalah seminar/ Prosiding konferensi :

Departemen Pendidikan dan Kebudayaan

(2013). Materi Pelatihan Guru dan

Implementasi Kurikulum 2013.

Jakarta: Depdikbud

Hidayat, Y. (2010). Jurnal Pendidikan

Jasmani dan Olahraga. Bandung:

FPOK UPI.

Suherman, A. (2013). Kreativitas dan

Aktivitas Jasmani pada Siswa

Kelas Rendah. Seminar nasional

Olahraga Universitas Pendidikan

Indonesia. Bandung, UPI Press,

hlm 1-18 